\title{
Demequina salsinemoris sp. nov., isolated on agar media supplemented with ascorbic acid or rutin
}

\author{
Atsuko Matsumoto, Kengo Nakai, Kurimi Morisaki, Satoshi Ōmura \\ and Yōko Takahashi
}

Correspondence

Yōko Takahashi

ytakaha@lisci.kitasato-u.ac.jp
Kitasato Institute for Life Sciences, Kitasato University, 5-9-1 Shirokane, Minato-ku, Tokyo 1088641, Japan

\begin{abstract}
Three strains, $\mathrm{KV}-810^{\top}, \mathrm{KV}-811$ and $\mathrm{KV}-816$, were isolated from mangrove soil from a southern island in Japan on media supplemented with ascorbic acid or rutin. These strains contained L-ornithine as the diagnostic diamino acid in the cell-wall peptidoglycan and DMK- $9\left(\mathrm{H}_{4}\right)$ as the predominant menaquinone. The $\mathrm{G}+\mathrm{C}$ content of the DNA was $70-72 \mathrm{~mol} \%$. These characteristics in combination with 16S rRNA gene sequence analysis revealed that the novel strains belonged to the genus Demequina. The DNA-DNA hybridization values showed that the three new strains belonged to the same species, a novel species of the genus Demequina. Therefore strains $\mathrm{KV}-810^{\top}, \mathrm{KV}-811$ and $\mathrm{KV}-816$ are proposed as representing a novel species, Demequina salsinemoris sp. nov. The type strain is $\mathrm{KV}-810^{\top}\left(=\mathrm{DSM} 22060^{\top}=\mathrm{NBRC} 105323^{\top}\right)$.
\end{abstract}

Takahashi et al. (2003) reported that the apparent number of bacterial strains on an agar medium is increased by the addition of oxidant scavengers. Takahashi et al. (2006) proposed the genus Patulibacter, members of which were isolated using an agar medium supplemented with superoxide dismutase and which possessed demethylmenaquinone 7 (DMK-7) as the isoprenoid quinone. In this study, strains $\mathrm{KV}-810^{\mathrm{T}}, \mathrm{KV}-811$ and $\mathrm{KV}-816$ were isolated using agar media supplemented with ascorbic acid or rutin as free-radical scavengers. The strains contained DMK-9 $\left(\mathrm{H}_{4}\right)$ as a diagnostic isoprenoid quinone. Actinobacterial species containing demethylmenaquinone are uncommon and it is known that the characteristic feature of the genus Demequina (Yi et al., 2007) is the presence of demethylmenaquinone DMK-9 $\left(\mathrm{H}_{4}\right)$. At present, the genus Demequina consists of two recognized species, Demequina aestuarii and Demequina lutea. In this study, the taxonomic characteristics of the isolated strains are reported and a novel species of the genus Demequina is described.

Strains $\mathrm{KV}-810^{\mathrm{T}}$, KV-811 and $\mathrm{KV}-816$ were isolated from mangrove soil of Amami Island, which lies in the sea south of Kagoshima Prefecture, Japan. Soil ( $1 \mathrm{~g}$ ) was diluted and spread on GPM plates ( $1 \%$ glucose, $0.5 \%$ peptone, $0.5 \%$ meat extract, $0.3 \% \mathrm{NaCl}, 1.2 \%$ agar; $\mathrm{pH} 7.0)$ containing Benlate $\left(20 \mathrm{mg} \mathrm{l}^{-1}\right.$; DuPont) with ascorbic acid

The GenBank/EMBL/DDBJ accession numbers for the $16 \mathrm{~S}$ rRNA gene sequences of strains $\mathrm{KV}-810^{\top}, \mathrm{KV}-811$ and $\mathrm{KV}-816$ are $\mathrm{AB} 471559$, AB471560 and AB471561, respectively.

Scanning electron micrographs of cells of strains $\mathrm{KV}-810^{\top}$ and $\mathrm{KV}-816$ and a supplementary table detailing the DNA-DNA relatedness values between strains $\mathrm{KV}-810^{\top}, \mathrm{KV}-811$ and $\mathrm{KV}-816$ and Demequina aestuarii $\mathrm{JC} 2054^{\top}$ are available with the online version of this paper. $\left(440 \mu \mathrm{g} \mathrm{l}^{-1}\right)$ or rutin $\left(120 \mu \mathrm{g}^{-1}\right)$, which are known to be free-radical scavengers. After cultivation at $27^{\circ} \mathrm{C}$, strains $\mathrm{KV}-810^{\mathrm{T}}$ and $\mathrm{KV}-811$ were isolated from GPM plates supplemented with ascorbic acid and strain KV-816 was isolated from GPM plates supplemented with rutin.

Morphological characteristics were observed by scanning electron microscopy (JSM 5600; JEOL) following incubation on TSY agar (3\% Bacto tryptic soy broth, $0.3 \%$ yeast extract, $1.2 \%$ agar) for 3 days at $27{ }^{\circ} \mathrm{C}$ and fixation by $4 \%$ osmium tetroxide vapour. API ZYM, API 20NE and API $50 \mathrm{CH}$ tests (bioMérieux) were used for biochemical characterization, according to the manufacturer's instructions. API ZYM and API 20NE tests were performed at $27{ }^{\circ} \mathrm{C}$ for $24 \mathrm{~h}$ and API $50 \mathrm{CH}$ was incubated at $72 \mathrm{~h}$ (except that the cultivation of D. lutea SV $45^{\mathrm{T}}$ was $20{ }^{\circ} \mathrm{C}$ for 1 week). Hydrolysis of casein and starch and decomposition of adenine, hypoxanthine, L-tyrosine and xanthine were examined on TSY agar according to Gordon et al. (1974) after incubation for 2 weeks at 27 or $20{ }^{\circ} \mathrm{C}$. YD agar ( $1.0 \%$ yeast extract, $1.0 \%$ glucose, $1.2 \%$ agar; $\mathrm{pH} 7.0$ ) was used for the $\mathrm{NaCl}$ tolerance test. TSY agar was used for the $\mathrm{pH}$ and temperature range tests. DNase test agar (Difco) was used for the DNase assay. Triple-sugar iron agar (Difco) was used to test for $\mathrm{H}_{2} \mathrm{~S}$ production. Results were recorded after cultivation for 2 weeks.

Biomass for chemotaxonomy was prepared by cultivation in TSY broth (3\% Bacto tryptic soy broth, $0.3 \%$ yeast extract) for 5 days at $27{ }^{\circ} \mathrm{C}$. $\mathrm{N}$-Acyl types of muramic acid were determined by the method of Uchida \& Aida (1977). Purified cell-wall extracts were obtained using the method of Kawamoto et al. (1981) and the amino acid composition of hydrolysed cell walls was determined by HPLC using the 
Pico-Tag method (Waters). The presence of mycolic acids was examined by TLC according to Tomiyasu (1982) and phospholipids were extracted and identified following the method of Minnikin et al. (1977). Menaquinones were extracted and purified by the method of Collins et al. (1977) and were subsequently analysed by LCMS (JMS T100LP; JEOL) with a Pegasil ODS column $(20 \times 50 \mathrm{~mm})$ using methanol/2-propanol $(7: 3)$. Biomass for analysis of fatty acids was prepared by culturing on TSY agar for 5 days at $27{ }^{\circ} \mathrm{C}$ and analysis was performed according to the procedures for the Sherlock Microbial Identification System (Microbial ID).

Chromosomal DNA was isolated as described by Saito \& Miura (1963), with some modifications. DNA base composition was estimated by the HPLC method of Tamaoka \& Komagata (1984). DNA-DNA hybridization experiments were performed as described by Ezaki et al. (1989). 16S rRNA gene sequences were obtained using previously described methods (Matsumoto et al., 2008). CLUSTAL_X version 1.83 (Thompson et al., 1994) was used for multiple alignments with selected sequences and for calculating evolutionary distances (Kimura, 1980). A phylogenetic tree was constructed based on the neighbour-joining method (Saitou \& Nei, 1987). Data were resampled with 1000 bootstrap replications (Felsenstein, 1985). For the creation of a phylogenetic tree by the maximum-likelihood method (Felsenstein, 1981), PHYLIP version 3.67 was used. Sequence similarity values were determined by visual comparison and manual calculation.

The cell-wall peptidoglycan of strains $\mathrm{KV}-810^{\mathrm{T}}$, KV-811 and $\mathrm{KV}-816$ contained L-ornithine as the diamino acid and alanine, serine and glutamic acid. The acyl type of the peptidoglycan was acetyl. The predominant menaquinone was DMK-9 $\left(\mathrm{H}_{4}\right)$. Mycolic acids were not detected. Only unidentified phospholipids were detected and phosphatidylinositol, diphosphatidylglycerol, phosphatidylethanolamine and phosphatidylcholine were absent. The $\mathrm{G}+\mathrm{C}$ content of the genomic DNA was $70-72 \mathrm{~mol} \%$.

Almost-complete 16S rRNA gene sequences for strains KV$810^{\mathrm{T}}$ (1436 bp), KV-811 (1395 bp) and KV-816 (1386 bp) were determined. The sequence similarity between the three strains was $100.0 \%$, indicating that they belonged to the same species. Phylogenetic analysis with the neighbourjoining and the maximum-likelihood methods showed that these strains were closely related to the genus Demequina of the suborder Micrococcineae (Fig. 1). Although the phylogenetic and chemotaxonomic data clearly showed that the strains belonged to the genus Demequina, the 16S rRNA gene sequence similarity values between the new isolates and D. aestuarii $\mathrm{JC} 2054^{\mathrm{T}}$ and $D$. lutea $\mathrm{SV} 45^{\mathrm{T}}$ were low (96.9 and $95.5 \%$, respectively).

Strains KV-810 ${ }^{\mathrm{T}}, \mathrm{KV}-811$ and KV-816 grew well on TSY agar, TSB agar and YD agar at $27^{\circ} \mathrm{C}$ and colonies were pale yellow. Cells were non-motile and rods $(0.3-0.4 \times 0.7-$ $1.1 \mu \mathrm{m}$ ) (see Supplementary Fig. S1, available in IJSEM Online).

The physiological differences between strains $\mathrm{KV}-810^{\mathrm{T}}$, $\mathrm{KV}-811$ and KV-816, D. aestuarii JC2054 ${ }^{\mathrm{T}}$ and D. lutea $\mathrm{SV} 45^{\mathrm{T}}$ are shown in Table 1. All three isolates showed some differences from the recognized species of the genus Demequina. The range of sodium chloride concentration for growth of the isolates was $0-8 \%(\mathrm{w} / \mathrm{v}) ; D$. aestuarii was strongly tolerant $(12 \%)$ and D. lutea was sensitive $(2 \%)$. Strain $\mathrm{KV}-810^{\mathrm{T}}$ and the type strains of the two recognized

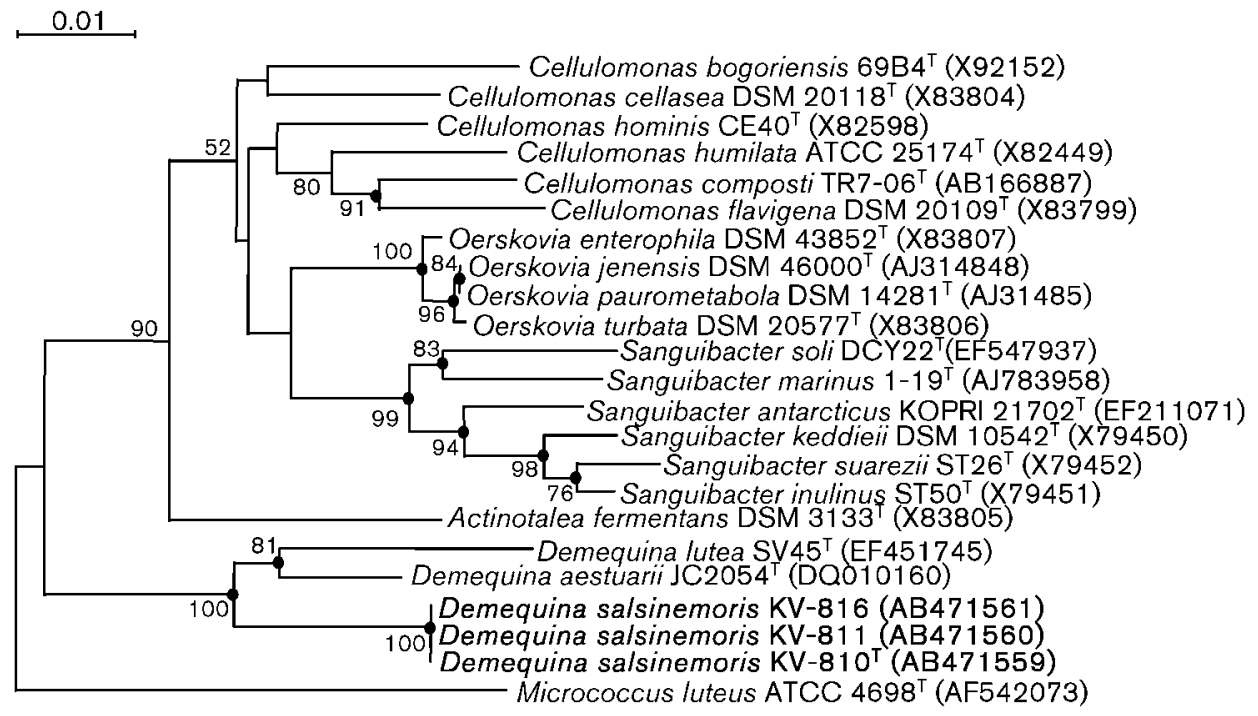

Fig. 1. Phylogenetic tree derived from 16S rRNA gene sequences and constructed using the neighbour-joining method. Bootstrap values ( $>50 \%$ ) based on 1000 replications are shown at branch nodes. Solid circles indicate that the corresponding nodes were also recovered in the maximum-likelihood tree. Bar, 1 substitution per nucleotide position. 
Table 1. Differential phenotypic characteristics of strains $\mathrm{KV}-810^{\top}, \mathrm{KV}-811$ and $\mathrm{KV}-816$ and the type strains of species of the genus Demequina

Strains: $1, \mathrm{KV}-810^{\mathrm{T}}$; 2, KV-811; 3, KV-816; 4, D. aestuarii JC2054 ${ }^{\mathrm{T}}$; 5, D. lutea SV45 ${ }^{\mathrm{T}}$. +, Positive; w, weakly positive; - , negative.

\begin{tabular}{|c|c|c|c|c|c|}
\hline Characteristic & 1 & 2 & 3 & 4 & 5 \\
\hline Temperature range for growth $\left({ }^{\circ} \mathrm{C}\right)$ & $14-34$ & $12-34$ & $12-34$ & $5-35^{\star}$ & $4-30 \dagger$ \\
\hline $\mathrm{pH}$ range for growth & $6-9$ & $6-9$ & $5-9$ & $6-11^{*}$ & $6-9 \dagger$ \\
\hline Tolerance to $\mathrm{NaCl}(\%)$ & 8 & 8 & 8 & $12^{*}$ & $2 \dagger$ \\
\hline \multicolumn{6}{|l|}{ API ZYM } \\
\hline Acid phosphatase & W & $\mathrm{W}$ & $\mathrm{W}$ & - & + \\
\hline Alkaline phosphatase & - & - & - & W & - \\
\hline Esterase lipase (C8) & $\mathrm{W}$ & $\mathrm{w}$ & $\mathrm{w}$ & - & - \\
\hline Naphthol-AS-BI-phosphohydrolase & $\mathrm{W}$ & w & w & w & - \\
\hline$\alpha$-Galactosidase & $\mathrm{W}$ & w & w & - & + \\
\hline$\alpha$-Glucosidase & + & + & + & - & + \\
\hline \multicolumn{6}{|l|}{ API $50 \mathrm{CH}$} \\
\hline D-Arabinose & - & - & - & + & - \\
\hline D-Galactose & + & + & + & - & $\mathrm{w}$ \\
\hline Gentiobiose & + & + & + & + & - \\
\hline Maltose & + & + & + & - & + \\
\hline L-Rhamnose & + & + & + & - & - \\
\hline Sucrose & - & - & - & + & + \\
\hline Trehalose & - & - & - & - & + \\
\hline Amygdalin & + & + & + & + & - \\
\hline Arbutin & + & + & + & - & - \\
\hline Methyl $\beta$-D-xylopyranoside & + & + & + & - & $\mathrm{W}$ \\
\hline
\end{tabular}

${ }^{*}$ Data from Yi et al. (2007).

$\dagger$ Data from Finster et al. (2009).

species of the genus Demequina possessed anteiso- $\mathrm{C}_{15: 0}$, anteiso- $\mathrm{C}_{17: 0}$ and $\mathrm{C}_{16: 0}$ as the dominant cellular fatty acids (Table 2).

Among the three new isolates, the DNA-DNA hybridization values were $74-99 \%$. The DNA-DNA hybridization

Table 2. Cellular fatty acid contents (\%) of strain $\mathrm{KV}-810^{\top}, D$. aestuarii $\mathrm{JC} 2054^{\top}$ and $D$. lutea $\mathrm{SV} 45^{\top}$

Strains: $1, \mathrm{KV}-810^{\mathrm{T}}$; 2, D. aestuarii $\mathrm{JC} 2054^{\mathrm{T}} ; 3$, D. lutea SV45 ${ }^{\mathrm{T}}$. Data were taken from this study, Yi et al. (2007) and Finster et al. (2009). Fatty acids that represented $<1 \%$ are omitted.

\begin{tabular}{|lrrr|}
\hline Fatty acid & $\mathbf{1}$ & $\mathbf{2}$ & $\mathbf{3}$ \\
\hline Saturated & & & \\
$\quad \mathrm{C}_{14: 0}$ & 5.8 & 1.6 & 1.8 \\
$\mathrm{C}_{15: 0}$ & 1.6 & 4.2 & 3.2 \\
$\mathrm{C}_{16: 0}$ & 15.6 & 10.4 & 1.4 \\
Branched & & & \\
iso- $\mathrm{C}_{14: 0}$ & 1.7 & 1.1 & 2.3 \\
iso- $\mathrm{C}_{15: 0}$ & 1.6 & 3.3 & 3.1 \\
anteiso-C & & \\
anteiso- $\mathrm{C}_{15: 1}$ & 45.7 & 46.8 & 59.4 \\
iso- $\mathrm{C}_{16: 0}$ & 1.5 & 10.2 & 6.4 \\
anteiso- $\mathrm{C}_{17: 0}$ & 6.3 & 7.0 & 8.9 \\
& 16.1 & 13.1 & 8.8 \\
\hline
\end{tabular}

values were very low (4-9\%) between the new isolates and D. aestuarii $\mathrm{JC} 2054^{\mathrm{T}}$ (see Supplementary Table S1 in IJSEM Online) and were below the $70 \%$ cut-off value recommended for the delineation of species (Wayne et al., 1987). On the basis of these results and the chemotaxonomic and phylogenetic analyses, we propose that strains $\mathrm{KV}-810^{\mathrm{T}}$, KV-811 and KV-816 represent a novel species of the genus Demequina, Demequina salsinemoris sp. nov.

\section{Description of Demequina salsinemoris sp. nov.}

Demequina salsinemoris (sal.si.ne.mo'ris. L. adj. salsus salted; L. n. nemus -oris wood; N.L. gen. n. salsinemoris of a salted wood, isolated from soil of a salted wood, a mangrove).

Cells are rods and $0.3-0.4 \times 0.7-1.1 \mu \mathrm{m}$ in size. Aerobic. The temperature range for growth is $12-34{ }^{\circ} \mathrm{C}$. Growth occurs at initial $\mathrm{pH}$ values of between 5 and $9 . \mathrm{NaCl}$ is tolerated, up to $8 \%(\mathrm{w} / \mathrm{v})$, but is not required. Good growth occurs on TSB agar and YD agar. Colonies are pale yellow. Catalase-positive and oxidase- and DNase-negative. $\mathrm{H}_{2} \mathrm{~S}$ is not produced. With API 20NE, hydrolysis of aesculin and $\beta$-galactosidase are positive, but nitrate reduction, indole production and acid production from glucose, arginine dihydrolase, urease and gelatin are negative. With API ZYM, acid phosphatase, esterase 
(C4), esterase lipase (C8), $\alpha$ - and $\beta$-galactosidases, $\alpha$ - and $\beta$-glucosidases, leucine arylamidase and naphthol-AS-BIphosphohydrolase are present, but $N$-acetyl- $\beta$-glucosaminidase, alkaline phosphatase, chymotrypsin, cystine arylamidase, $\alpha$-fucosidase, $\beta$-glucuronidase, lipase (C4), $\alpha$ mannosidase and trypsin and valine arylamidases are absent. With API 50CH, aesculin, amygdalin, L-arabinose, arbutin, cellobiose, D-fructose, D-galactose, gentiobiose, Dglucose, maltose, $\mathrm{D}$-mannose, methyl $\beta$-D-xylopyranoside, L-rhamnose, salicin and D-xylose are utilized as carbon sources but $\mathrm{N}$-acetyl-glucosamine, D-adonitol, D-arabinose, D- and L-arabitol, dulcitol, erythritol, D- and L-fucose, glycerol, glycogen, inositol, inulin, 2- and 5-ketogluconate, D-lactose, D-lyxose, D-mannitol, melezitose, melibiose, methyl $\alpha$-D-glucopyranoside, methyl $\alpha$-D-mannopyranoside, gluconate, raffinose, D-ribose, D-sorbitol, L-sorbose, starch, sucrose, D-tagatose, trehalose, turanose and xylitol are not utilized. Hydrolysis of casein and starch and decomposition of adenine, hypoxanthine, L-tyrosine and xanthine are negative. The predominant components of the cellular fatty acids are anteiso- $\mathrm{C}_{15: 0}$, anteiso- $\mathrm{C}_{17: 0}$ and $\mathrm{C}_{16: 0}$.

The type strain, $\quad \mathrm{KV}-810^{\mathrm{T}} \quad\left(=\mathrm{DSM} \quad 22060^{\mathrm{T}}=\mathrm{NBRC}\right.$ $105323^{\mathrm{T}}$ ), was isolated from mangrove soil of a southern island in Japan. The DNA G + C content of the type strain is $70-72 \mathrm{~mol} \%$.

\section{Acknowledgements}

This work was financially supported by the Institute for Fermentation, Osaka (IFO), Japan. We thank Professor Jean P. Euzéby for his help with the nomenclature.

\section{References}

Collins, M. D., Goodfellow, M. \& Minnikin, D. E. (1977). Distribution of menaquinones in actinomycetes and corynebacteria. J Gen Microbiol 100, 221-230.

Ezaki, T., Hashimoto, Y. \& Yabuuchi, E. (1989). Fluorometric deoxyribonucleic acid-deoxyribonucleic acid hybridization in microdilution wells as an alternative to membrane filter hybridization in which radioisotopes are used to determine genetic relatedness among bacterial strains. Int J Syst Bacteriol 39, 224-229.

Felsenstein, J. (1981). Evolutionary trees from DNA sequences: a maximum likelihood approach. J Mol Evol 17, 368-379.

Felsenstein, J. (1985). Confidence limits on phylogenies: an approach using the bootstrap. Evolution 39, 783-791.

Finster, K. W., Herbert, R. A., Kjeldsen, K. U., Schumann, P. \& Lomstein, B. A. (2009). Demequina lutea sp. nov., isolated from a high Arctic permafrost soil. Int J Syst Evol Microbiol 59, 649-653.
Gordon, R. E., Barnett, D. A., Handerhan, J. E. \& Pang, C. H.-N. (1974). Nocardia coeliaca, Nocardia autotrophica, and the nocardin strain. Int J Syst Bacteriol 24, 54-63.

Kawamoto, I., Oka, T. \& Nara, T. (1981). Cell wall composition of Micromonospora olivoasterospora, Micromonospora sagamiensis, and related organisms. J Bacteriol 146, 527-534.

Kimura, M. (1980). A simple method for estimating evolutionary rates of base substitutions through comparative studies of nucleotide sequences. J Mol Evol 16, 111-120.

Matsumoto, A., Yamada, M., Ōmura, S. \& Takahashi, Y. (2008). Microterricola viridarii gen. nov., sp. nov., a new member of the family Microbacteriaceae. Int J Syst Evol Microbiol 58, 1019-1023.

Minnikin, D. E., Patel, P. V., Alshamaony, L. \& Goodfellow, M. (1977). Polar lipid composition in the classification of Nocardia and related bacteria. Int J Syst Bacteriol 27, 104-117.

Saito, H. \& Miura, K. (1963). Preparation of transforming deoxyribonucleic acid by phenol treatment. Biochim Biophys Acta 72, 619-629.

Saitou, N. \& Nei, M. (1987). The neighbor-joining method: a new method for reconstructing phylogenetic trees. Mol Biol Evol 4, 406425.

Takahashi, Y., Katoh, S., Shikura, N., Tomoda, H. \& Ōmura, S. (2003). Superoxide dismutase produced by soil bacteria increases bacterial colony growth from soil samples. J Gen Appl Microbiol 49, 263-266.

Takahashi, Y., Matsumoto, A., Morisaki, K. \& Ōmura, S. (2006). Patulibacter minatonensis gen. nov., sp. nov., a novel actinobacterium isolated using an agar medium supplemented with superoxide dismutase, and proposal of Patulibacteraceae fam. nov. Int J Syst Evol Microbiol 56, 401-406.

Tamaoka, J. \& Komagata, K. (1984). Determination of DNA base composition by reversed-phase high-performance liquid chromatography. FEMS Microbiol Lett 25, 125-128.

Thompson, J. D., Higgins, D. G. \& Gibson, T. J. (1994). CLUSTAL W: improving the sensitivity of progressive multiple sequence alignment through sequence weighting, position specific gap penalties and weight matrix choice. Nucleic Acids Res 22, 4673-4680.

Tomiyasu, I. (1982). Mycolic acid composition and thermally adaptative changes in Nocardia asteroides. J Bacteriol 151, 828837.

Uchida, K. \& Aida, K. (1977). Acyl type of bacterial cell wall: its simple identification by colorimetric method. J Gen Appl Microbiol 23, 249260.

Wayne, L. G., Brenner, D. J., Colwell, R. R., Grimont, P. A. D., Kandler, O., Krichevsky, M. I., Moore, L. H., Moore, W. E. C., Murray, R. G. E. \& other authors (1987). International Committee on Systematic Bacteriology. Report of the ad hoc committee on reconciliation of approaches to bacterial systematics. Int J Syst Bacteriol 37, 463464.

Yi, H., Schumann, P. \& Chun, J. (2007). Demequina aestuarii gen. nov., sp. nov., a novel actinomycete of the suborder Micrococcineae, and reclassification of Cellulomonas fermentans Bagnara et al. 1985 as Actinotalea fermentans gen. nov., comb. nov. Int J Syst Evol Microbiol 57, 151-156. 